\title{
Microfungi, algae and cyanobacteria in soils polluted with fluo- rine (Kola Peninsula, Russia)
}

\author{
Vera V. Redkina ${ }^{*}$, Regina R. Shalygina, Mariya V. Korneykova \\ Institute of North Industrial Ecology Problems, Subdivision of Kola Science Center of \\ the Russian Academy of Science, Apatity, Russia
}

\begin{abstract}
The analysis of algal-mycological complexes in Albic Podzolic soils affected by emissions of the Kandalaksha Aluminum Smelter (KAS) was carried out. The number and biomass of microscopic fungi in the maximum fluorine-polluted zone (fluorine-content $>1000 \mathrm{mg} / \mathrm{kg}$ ) more than 2 times lower than in distanced areas and amounted to 17.3 thousants colony-forming units/g and $1.33 \mathrm{mg} / \mathrm{g}$ respectively. Altogether, 31 species of soil fungi were isolated. The species Penicillium trzebinskii and P. miczynskii dominated the zone of maximum pollution. P. glabrum, P. spinulosum, and Memnoniella echinata prevailed in the zones of moderate pollution and background. The part of opportunistic fungi in contaminated soil increased in comparison with the background soil. The reduction of dark-colored fungi biomass in contaminated soil was noted. In total, 56 species of eukaryotic algae and 7 species of cyanobacteria were found. Among green algae, the species from families Chlorophyceae and Trebouxiophyceae dominated in all plots. In the zones of maximum and strong contamination, 53 algae species were found including xanthophytes, which were absent in unpolluted areas. The number of viable cells in the litter of the maximum contaminated soils varied from 100 thousand to 1.5 million in $1 \mathrm{~g}$ of absolutely dry soil. The species composition of algae and cyanobacteria in these soils showed the characteristic features of the Arctic biological soil crusts.
\end{abstract}

Key words: fluorine, Kandalaksha aluminum smelter, soil contamination, biodiversity, fungi, algae, cyanobacteria

DOI: $10.5817 / \mathrm{CPR} 2020-1-9$

\section{Introduction}

The problem of environmental pollution by industrial emissions is a topical for the Kola Peninsula whereas the territory is affected by intensive aerial industrial im- pact from non-ferrous metallurgy plants, the Kandalaksha Aluminum Smelter (KAS) in particular (see Fig. 1). The KAS affiliated with the Russian Aluminum Company

Received March 23, 2020, accepted July 2, 2020.

*Corresponding author: V. V. Redkina $<$ regina_rinat@mail.ru>

Acknowledgements: The research was carried out within the state assignment of Ministry of Science and Higher Education of the Russian Federation (theme No. AAAA-A18-1180214900705). The authors are grateful to Doctor of Biological Science Professor G.A. Evdokimova, the chief of the Laboratory of Ecology of Microorganisms, for the concept of this study and valuable consultations in the course of the work. We also thank PhD V.A. Myazin for his aid during the fieldwork. 
(RUSAL) is the only aluminum plant in the world located beyond the Arctic Circle. Aluminum is produced by the Soderberg technology which is widely applied in Russia and is a source of ecological risks (Barber and Tabereaux 2014, Ghosh et al. 2014, Gibbs and Labrèche 2014). The gas emissions from the KAS contain a wide variety of pollutants including fluorine compounds, polycyclic aromatic hydrocarbons, resinous substances and inorganic dust. These elements can be distributed to the long distances from the source of the contamination (up to $15-20 \mathrm{~km}$ ). The main compounds in the aerial emissions from KAS are fluorine and aluminum (Evdokimova et al. 2013). Fluorine and its compounds belong to the group of hazardous substances for living organisms including humans (Gibbs and Labrèche 2014, Chaschin 2017, Kongerud 2007, Taiwo 2007). Fluorine is found in emissions basically in water-soluble form accessible for biota (45 kg F per 1 hectare) (Evdokimova et al. 2005).

There are about 240 aluminum plants in the world, 17 of them are located in the Russian Federation [1]. Despite this, the studies of the impact of industrial emissions of aluminum plants on soils of the adjacent territories are scarce. Thus, Norwegian scientists have studied the accumulation and transport of fluorine in soil profiles near the smelter at Årdal (Vestland county, West Norway) as well as sorption and desorption of added fluorine in representative soil and the effect of $\mathrm{pH}$ and ionic strength on desorption of fluorine in soil (Arnesen and Krogstad 1998). The study of prolonged fluoride pollution of soils near the aluminum smelter in Central Slovakia revealed the decreases in microbial and enzymatic activities as well as in soil microbial biomass $\mathrm{C}$ to organic $\mathrm{C}$ ratio (GarcíaGil et al. 2013). The most studied territories of Russia, exposed to the emissions from aluminum industry, are located in the vicinity of the Krasnoyarsk and Irkutsk alu- minum smelters (Demidenko and Zhbankichov 2014, Tandelov 2012, Kozlova et al. 2011, Kirillova and Pomazkina 2014, Sokolova and Zorina 2015, Lomovatskaya et al. 2014, Pomazkina et al. 2008). The response of the microbial soil components was studied through the index of specific respiratory activity (Sokolova et al. 2011). Other researchers have shown a significant decrease in the number and species diversity of soil micromycetes, inhibition of actinomycetes and nonspore-forming bacteria affected by industrial emissions of Irkutsk Aluminum Plant (Beresneva et al. 2010, Beresneva 2015).

At present, it is known that fluorine from gas-air emissions of smelters fall into the soil with the dust particles, atmospheric precipitations. Vascular plants uptake it by root system and accumulate in aboveground organs, especially in leaves. Bioavailability of fluorine in soil depends on the concentration of its soluble forms, the type of chemical compound, and $\mathrm{pH}$ value. The minimum solubility occurs at $\mathrm{pH}$ values between 5.5 and 6.5 (Stevens et al. 2000, Larsen and Widdowson 1971). Above $\mathrm{pH} 6$, the anion $\mathrm{F}^{-}$is prevailing, however, HF and the various soluble complexes with other elements are dominate at lower pHs: $\mathrm{SiF}_{6}{ }^{2-}, \mathrm{AlF}_{2}{ }^{+}, \mathrm{AlF}_{2}{ }^{+}, \mathrm{AlF}_{3}{ }^{0}$, $\mathrm{AlF}_{4}^{-}$, and $\mathrm{BF}_{4}^{-}$(Stevens et al. 1998). Stevens et al. (2000) noted that the species of fluoride is most available for the plants, including HF and some of aluminum complexes. The permeability of cell membranes is much greater for these substances than for $\mathrm{F}^{-}$anion (Armstrong and Singer 1980, Gutknecht and Walter 1981, Stevens et al. 2000). Therefore, the fluorine toxicity increases in acidic soils.

Phototrophic microorganisms (algae and cyanobacteria) and microscopic fungi (micromycetes) performing diametrically opposite functions in trophic chains can reflect the effect of fluorine on microbiological processes. 

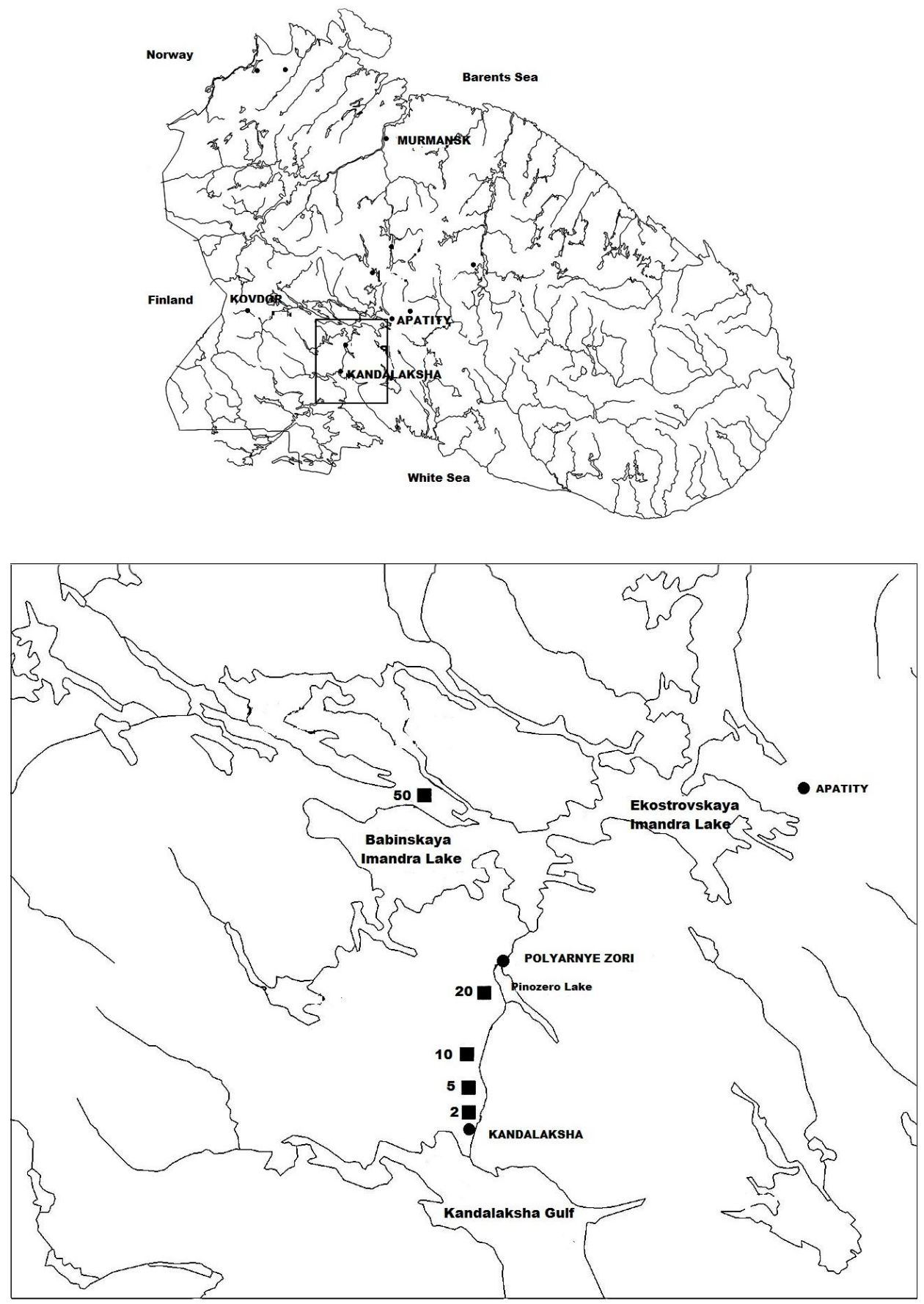

Fig. 1. Map showing the studied area. 
The changes might be indicative of changes in production and decomposition potential in soils (Domracheva et al. 2006). A number of studies summarized in $\mathrm{Ca}$ margo (2003) have shown the effect of fluorine and its complexes with aluminum on algae in experimental conditions. Negative effect of fluorine on cell membranes, inhibition of photosynthesis, respiration, and nitrogen fixation have been reported. However, eukaryotic algae are more resistant to the toxic effect of fluorine than cyanobacteria due to the presence of a cellulose cell wall and cell compartmentalization (Bhatnagar and Bhatnagar 2000). Fluorine can inhibit the soil fungi. This is confirmed by laboratory experiments with growing fungi on fluoride-containing media. For example, the Verticillium lecanii

\section{Material and Methods}

The field studies were performed on stationary monitoring plots in the aerial pollution gradient from the KAS within $0.5,2,5,10,20$, and $50 \mathrm{~km}$ to the north of the smelter (prevailing wind direction according to wind rose diagram). The latter plot was considered as the background (control). The studied area represents the southern part of the Imandra Depression separating the Kola Peninsula from western continental Fennoscandia $\left(60^{\circ} 09^{\prime} 25^{\prime \prime}\right.$ $\left.\mathrm{N}, 32^{\circ} 24^{\prime} 42^{\prime \prime} \mathrm{E}\right)$. The soils of all the monitored plots are Albic Podzols developed from sandy moraine deposits with a high content of boulders. All the plots were established in pine forests with dwarf shrubs (mostly crowberry Empetrum hermaphroditum) and mosses in the ground cover. The thickness of the organic horizon ranged 3$5 \mathrm{~cm}$.

The soil moisture was determined in weighed soil samples dried in an oven at $105^{\circ} \mathrm{C}$ until the constant weight. The soil acidity was determined by the potentiometric method with a Radelkis OP-300 laboratory $\mathrm{pH}$ meter equipped with a com- grew on a medium containing about $0.2 \mathrm{M}$ $\mathrm{NaF}$ (Leslie and Parberry 1972), but increase of fluorine concentration has inhibited their growth. Similarly, Treshow (1965) showed inhibition of growth of some fungi at concentrations in media as low as $5 \times 10^{-4} \mathrm{M} \mathrm{NaF}$ (for Pythium debaryanum) and only one species (Colletotrichum lindemuthianum) was stimulated by $1 \times 10^{-3} \mathrm{M} \mathrm{NaF}$ at $24^{\circ} \mathrm{C}$.

Since fluorine compounds are toxic to living organisms, long-term soil contamination with fluorine-containing emissions from an aluminum plant should affect the state of soil microbiota. Therefore, the aim of this study is to determine how the number and species diversity of micromycetes and algae change depending on the level of soil contamination with fluoride.

bined $\mathrm{pH}$ electrode in the 1:2.5 water soil extracts.

The number of fungi was evaluated using the plating method on the worth agar. For microbostatic effect, lactic acid (4 ml per $1 \mathrm{~L}$ medium) was added. Species were identified by morphological characteristics using a microscope Olympus CX 41 (Japan) with the camera Jenoptic ProgRes CT3 (Germany). A variety of identification guides were used (Raper and Thom 1968, Egorova 1986, Klich 2002, Domsh et al. 2007, Seifert et al. 2011) according to the replenished species lists in the Species Fungorum database [2]. The fungi biomass and mycelium length were calculated by Olsen' method with some modification (Olsen and Hovland 1985, Evdokimova and Mozgova 1996, Mirchink 1988). Soil suspensions after staining with acridine orange and FITC (SIGMA, Japan) were passed through Whatman $\mathbb{}$

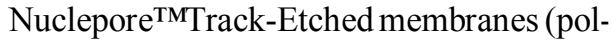
ycarbonate, black) with $0.8 \mu \mathrm{m}$ pore size. The hyphae length was calculated based on the number of intersections of the hy- 
phae with the lines of a square grid inserted into the eyepiece.

Living algae cells were counted in dried smears of soil suspensions using fluorescence microscopy method (Treshow 1965). For the analysis of species diversity, soil samples were placed in Z8 and BBM liquid media and in Petri dishes with the same agarized culture media (Gaisina et al. 2008, Kotai 1972). Species were identified by morphological characteristics using a number of guides Andreeva (1998), Ettl and Gärtner (2014), Komárek and Anagnostidis (1998, 2005), and Komárek (2013). The species names and taxonomic affiliation were clarified by electronic database AlgaeBase [3]. Algae and cyanobacteria communities were analyzed using Søren-

\section{Results and Discussion}

According to previous studies there are four zones under anthropogenic impact that have been selected by pollution gradient (Evdokimova et al. 2013) (Table 1). The fluorine content decreases from $1000 \mathrm{mg} /$ $\mathrm{kg}$ in the zone of maximum contamination to $200 \mathrm{mg} / \mathrm{kg}$ in the background zone. The aerial pollution has affected the soil prop-
sen-Chekanovsky coefficient and similarity measurement (for average distance) in GRAPHS clustering program (Novakovskii 2004).

The frequency of occurrence of micromycetes or algae species was calculated from the equation (Kondrat'eva and Kovalenko 1975, Kurakov 2001): $\mathrm{B}=(\mathrm{a} / \mathrm{A}) \times$ 100 , where $\mathrm{B}$ is occurrence, $\%$; $\mathrm{a}$ is the number of samples containing the certain species; and $\mathrm{A}$ is the total number of the samples. The abundance of fungi species was calculated from the equation: $\mathrm{C}=$ $(\mathrm{n} / \mathrm{N}) \times 100$, where $\mathrm{C}$ is abundance, \%; $\mathrm{n}$ is a number of isolates of the certain species, and $\mathrm{N}$ is the total number of isolates of all species.

erties. The natural litter horizons in this region are characterized by acidity due to intense leaching of the soils (Nikonov and Koptsik 1999). In the zone of the maximal contamination, the acidity of the litter is significantly lower than on the background plot (pH 5.6 against $\sim 4$ ).

\begin{tabular}{|l|c|c|c|c|}
\hline Contamination & $\begin{array}{c}\text { Distance from } \\
\text { KAS }[\mathbf{k m}]\end{array}$ & $\begin{array}{c}\text { Concentration of } \\
\mathbf{F}, \mathbf{[ m g} / \mathbf{k g}]\end{array}$ & $\mathbf{p H}$ & $\begin{array}{c}\text { Moisture } \\
{[\mathbf{\%}]}\end{array}$ \\
\hline Maximum & $0-1.5$ & $>1000$ & $4.50-5.58$ & $83-160$ \\
\hline Strong & $1.5-8.0$ & $1000-400$ & $3.75-4.31$ & $87-338$ \\
\hline Moderate & $8.0-15$ & $400-200$ & $3.78-4.71$ & $146-237$ \\
\hline Control & $>15$ & $<200$ & $3.57-3.96$ & $151-350$ \\
\hline
\end{tabular}

Table 1. Zones of litter pollution with fluorine.

\section{Microfungi}

The number and biomass of microscopic fungi in the maximum polluted zone (fluorine content $>1000 \mathrm{mg} / \mathrm{kg}$ ) was more than 2 times lower than in distanced areas and amounted to 17.3 thous. CFU/g and $1.33 \mathrm{mg} / \mathrm{g}$ respectively (Fig. 2). A sig- nificant negative correlation was found between the number and biomass of micromycetes and the content of water-soluble fluorine $(r=-0.77$ and -0.98 at $p<0.05$ respectively). 


\begin{tabular}{|c|c|c|c|}
\hline \multirow[b]{2}{*}{ Species } & \multicolumn{2}{|c|}{ Zones of contamination } & \multirow[b]{2}{*}{$\begin{array}{c}\text { Control } \\
\text { (F content } \\
<200 \mathrm{mg} / \mathrm{kg})\end{array}$} \\
\hline & $\begin{array}{c}\text { Maximum } \\
\text { and Strong } \\
(\text { F content } \\
>400 \mathrm{mg} / \mathrm{kg})\end{array}$ & $\begin{array}{c}\text { Moderate } \\
\text { (F content } \\
400-200 \\
\mathrm{mg} / \mathrm{kg})\end{array}$ & \\
\hline \multicolumn{4}{|c|}{ Division Zygomycota Class Incertae sedis Order Mucorales Family Umbelopsidaceae } \\
\hline $\begin{array}{l}\text { Umbelopsis isabellina (Oudem.) } \\
\text { W. Gams }\end{array}$ & 0.3 & 1.3 & 1.1 \\
\hline \multicolumn{4}{|c|}{ Family Mucoraceae } \\
\hline Mucor hiemalis Wehmer & & 4.7 & 1.7 \\
\hline Mucor sp. & 0.06 & 3.2 & 1.9 \\
\hline \multicolumn{4}{|c|}{ Order Mortierellales Family Mortierellaceae } \\
\hline $\begin{array}{l}\text { Umbelopsis longicollis (Dixon- } \\
\text { Stew.) Y. N. Wang, X.Y.Liu et } \\
\text { R.Y. Zheng }\end{array}$ & & 0.3 & 3.5 \\
\hline \multicolumn{4}{|c|}{ Division Ascomycota Class Eurotiomycetes Order Eurotiales Family Trichocomaceae } \\
\hline Penicillium corylophilum Dierckx & 0.4 & & \\
\hline P. implicatum Biourge & & 0.3 & 2.8 \\
\hline P. jensenii K. M. Zaleski & 0.4 & & \\
\hline P. glabrum (Wehmer) Westling & 19.7 & 84.2 & 50 \\
\hline P. lividum Westling & 1.8 & 1.3 & \\
\hline P. miczynskii K. M. Zaleski & 25.3 & & \\
\hline P.nalgiovense Laxa & 1.6 & & \\
\hline P. nigricans K. M. Zaleski & & 2.5 & 1.1 \\
\hline P. raistrickii G. Sm. & & 1.3 & 1.1 \\
\hline $\begin{array}{l}\text { P.restrictum J. C. Gilman et E.V. } \\
\text { Abbott }\end{array}$ & 1.9 & 1.3 & 8.9 \\
\hline P. simplicissimum (Oudem.) Thom & 1.4 & 0.08 & 1.1 \\
\hline P. spinulosum Thom & 13.2 & 18.4 & 31.3 \\
\hline P. thomii Maire & 0.6 & 0.2 & 1.1 \\
\hline P. trzebinskii K. M. Zaleski & 36.5 & 2.6 & 2.1 \\
\hline \multicolumn{4}{|c|}{ Order Chaetothyriales Family Herpotrichiellaceae } \\
\hline $\begin{array}{l}\text { Exophiala jeanselmei (Langeron) } \\
\text { McGinnis et A. A. Padhye }\end{array}$ & 2.5 & & \\
\hline \multicolumn{4}{|c|}{ Class Sordariomycetes Order Microascales Family Microascaceae } \\
\hline $\begin{array}{l}\text { Scopulariopsis brumptii Salv. - } \\
\text { Duval }\end{array}$ & 3.9 & & \\
\hline \multicolumn{4}{|c|}{ Order Hypocreales Family Hypocreaceae } \\
\hline Trichoderma koningii Oudem & 0.6 & & \\
\hline T. polysporum (Link) Rifai & & & 0.4 \\
\hline T. viride Pers. & 1.8 & 1.3 & 0.5 \\
\hline \multicolumn{4}{|c|}{ Family Incertae sedis } \\
\hline $\begin{array}{l}\text { Memnoniella echinata (Rivolta) } \\
\text { Galloway }\end{array}$ & 6.3 & 18.7 & 26 \\
\hline \multicolumn{4}{|c|}{ Order Microascales Family Microascaceae } \\
\hline $\begin{array}{l}\text { Wardomyces anomalus } \\
\text { F. T. Brooks et Hansf. }\end{array}$ & & & 0.4 \\
\hline Wardomyces sp. & & 0.9 & \\
\hline
\end{tabular}




\begin{tabular}{|c|c|c|c|}
\hline \multicolumn{4}{|c|}{ Order Hypocreales Family Incertae sedis } \\
\hline Acremonium rutilum W. Gams & & & 0.2 \\
\hline \multicolumn{4}{|c|}{ Class Dothideomycetes Order Dothideales Family Dothioraceae } \\
\hline $\begin{array}{l}\text { Aureobasidium pullulans } \\
\text { (De Bary et Lowenthal) Arnaud }\end{array}$ & 0.6 & 1.1 & 0.3 \\
\hline \multicolumn{4}{|c|}{ Family Incertae sedis } \\
\hline Phoma sp. & & & 0.2 \\
\hline \multicolumn{4}{|c|}{ Order Capnodiales Family Davidiellaceae } \\
\hline Amorphotheca resinae Parbery & & 2.7 & 21.3 \\
\hline \multicolumn{4}{|c|}{ Class Incertae sedis Order Incertae sedis Family Incertae sedis } \\
\hline Sterilia mycelia dark & 60.5 & 46.7 & 31 \\
\hline Torula allii (Harz) Sacc & 11.2 & 10.7 & 21.7 \\
\hline
\end{tabular}

Table 2. Species diversity and abundance (\%) of soil microscopic fungi in the area of the Kandalaksha Aluminum Smelter.
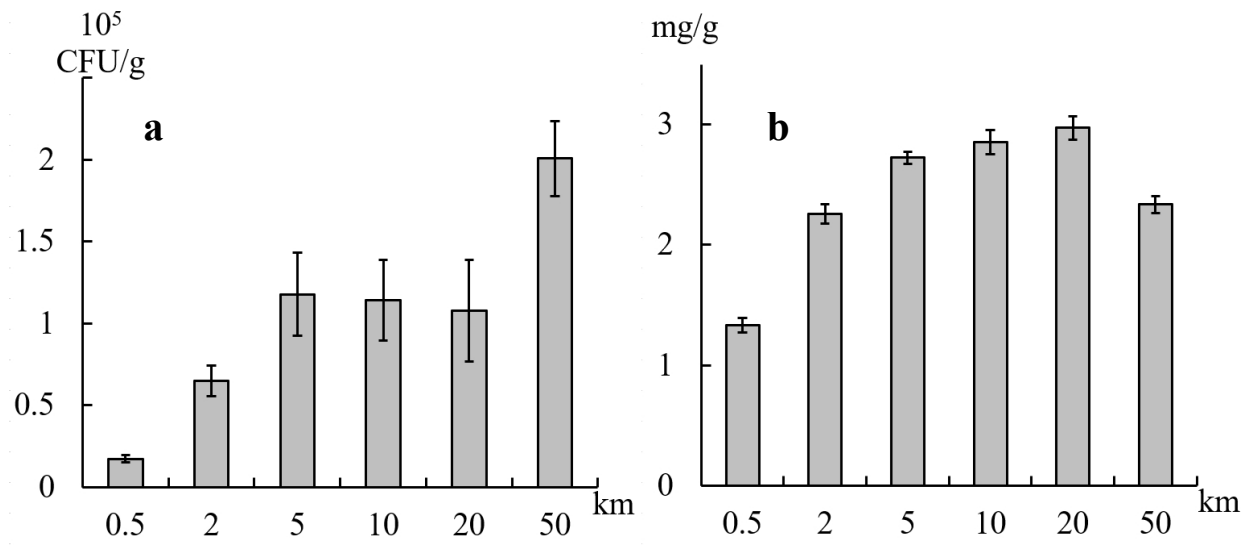

Fig. 2. Fungi number (a) and biomass (b) in the litter depends on pollution gradient.

The species diversity of microscopic fungi complexes in the KAS zone is represented by 31 species belonging to 14 genera, 14 families, 11 orders, 5 classes, 2 divisions and a group of fungi with sterile mycelium (Table 2).

The species Exophiala jeanselmei, Peniicillium corylophilum, P. jensenii, P. miczynskii, P. nalgiovense, Scopulariopsis brumptii, Trichoderma koningii were isolated only $2 \mathrm{~km}$ from emission source. Acremonium rutilum, T. polysporum, Wardomyces anomalus and fungi of the genus Torula were found only on the background area.
Species P. trzebinskii and P. miczynskii dominated in the maximum polluted zone. P. glabrum, P. spinulosum and Memnoniella echinata prevailed in the strong and moderately polluted zones. An increase of fungi diversity of genera Aspergillus, Fusarium, Alternaria, Cladosporium and a change of intrapartum structure of genus Penicillium have been found in polluted area i.e. the higher number of fungi from Biverticillata and Asymmetrica sections. These genera and structure of genus Penicillium are typical for soils of more southern regions. 
Changes in the abundance, structure, and composition of fungal communities in contaminated soil occured as the result of high fluorine compounds $(\geq 1000-1200 \mathrm{mg} / \mathrm{kg})$ in soil, and significant decrease in its acidity (about $2 \mathrm{pH}$ units), and increased competition with prokaryotes in a medium close to neutral.

In the polluted soil, the reduction of dark-colored fungi biomass was observed. In the background soil, $9 \%$ of the total biomass was presented by dark-colored fungi, in a moderately polluted area $-3 \%$, and in a highly polluted area- only $1 \%$. This fact is very interesting, but needs to be verified both on the basis of field studies and in laboratory experiments. Dark colored fungi, such as Alternaria and Cladosporium, were not isolated from the fluorine highly polluted soil, at the same time these fungi were random species in the moderate polluted soil. Microscopic fungi isolated from contaminated soil were often pathogenic comparing with the strains isolated from uncontaminated soil based on proteases, phospholipase activity and ability to grow at $37^{\circ} \mathrm{C}$.

\section{Algae}

The territory near KAS (by $0.5 \mathrm{~km}$ ) is characterized by drastically fluctuating number of algae and cyanobacteria in the litter from 100 thousand to 1.5 million cells per $1 \mathrm{~g}$ of absolutely dry soil (Fig. 3). Such fluctuations are explained by scarce vegetation, and therefore the soil here is very heterogeneous and sensitive to the effects of climatic environmental factors. The soil litter at a distance of $2 \mathrm{~km}$ from the plant was less populated by algae. Algae growth is inhibited because a high concentration of fluorine is combined with a low level of

soil pH (Table 1), therefore, the toxicity of fluorine increases. The cell number was about 130 thousand per $1 \mathrm{~g}$. In the $5-\mathrm{km}$ zone, the number of microphototrophs increased by 4 times and remained constant moving away from the source of emissions. The abundance of algae and cyanobacteria in the upper layer of soil without vegetation at the 0.5 and $2 \mathrm{~km}$ from the KAS was high and reached 2 and 8 million cells/g abs. dry soil, respectively, despite the very low soil moisture (6-8\%).

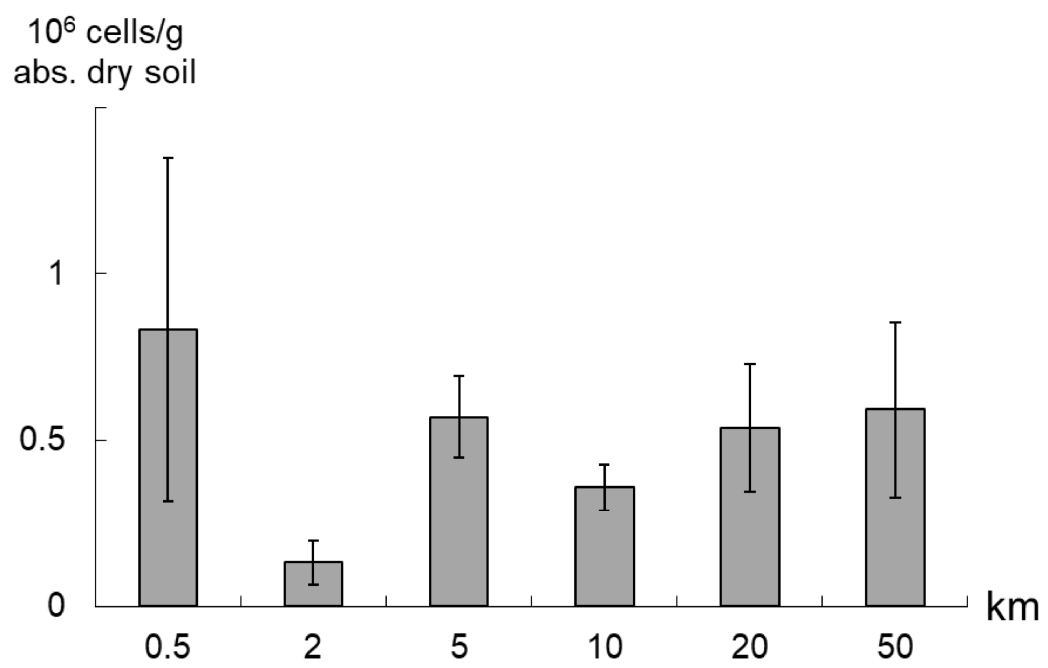

Fig. 3. Algae and cyanobacteria number in the litter depends on pollution gradient. 
In total, 63 species of microphototrophs from the divisions Chlorophyta (41 species), Charophyta (6), Ochrophyta (9), Cyanobacteria (7) were found (Table 3). Species diversity was represented by Chlorophyceae (19) and Trebouxiophyceae (18) as the dominants. The highest occurrence (above $60 \%$ ) revealed the following species: Pseudococcomyxa simplex, Stichococcus bacillaris, Neocystis brevis, Parietochloris alveolaris, Pleurastrum terricola, Halochlorella rubescens, Klebsormidium flaccidum, Vischeria magna, and Aphanocapsa sp. The representatives of Nostoc, Chlamydomonas, and Chlorococcum genera have been found in the all studied plots. The area of heavy contamination (by $5 \mathrm{~km}$ ) differed in taxonomic composition and species diversity of algae from the distant territories (Fig.4).

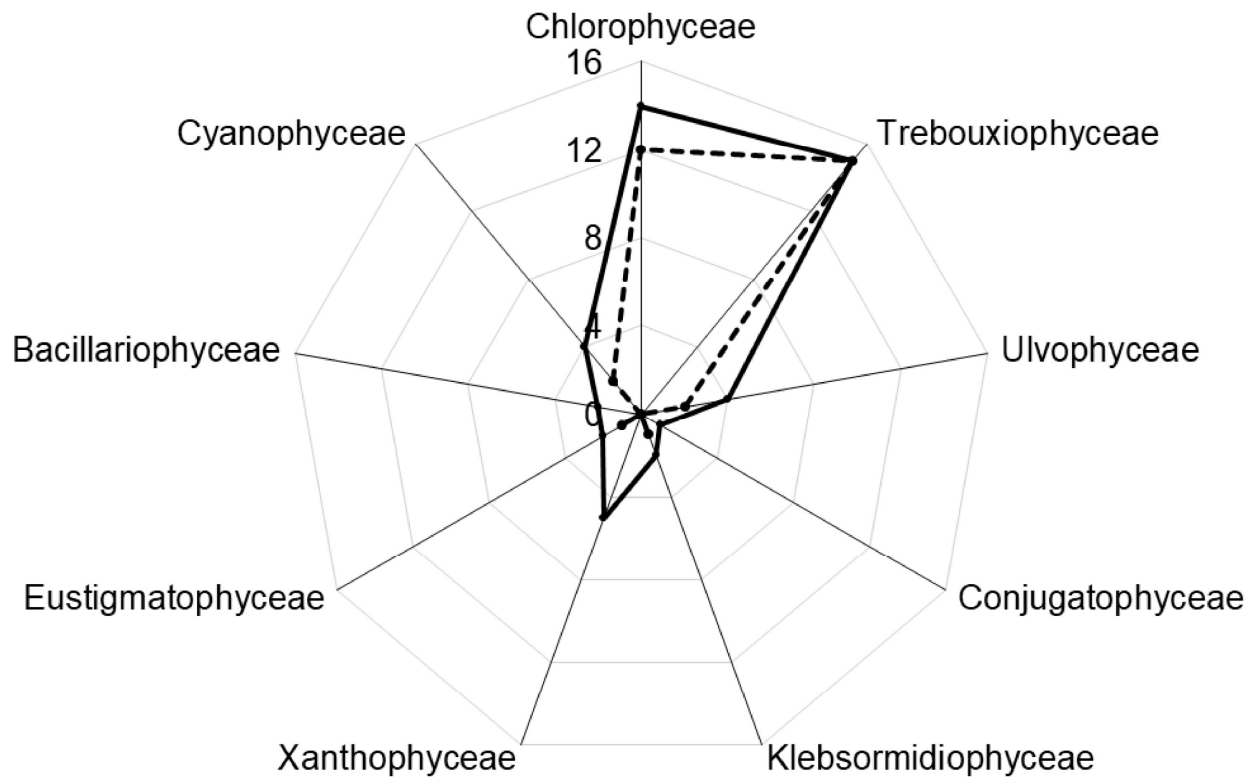

- The zones of maximum and strong contamination

\section{--.The zone of moderate contamination and uncontaminated area}

Fig. 4. Species diversity of algae and cyanobacterial communities at a level of classes in soils affected by KAS emissions including zones of maximum and severe pollution, as well as moderate pollution and its absence.

In the soil near the KAS, 53 species (about $80 \%$ of total number) were found. Xanthophytes were detected among these but absent in unpolluted areas. A greater variety of filamentous algae from the genus Klebsormidium was noted here. It is interesting that the species Keratococcus bicaudatus and Cylindrocystis brebissonii which are typical inhabits of wet areas, were found only in this zone. Earlier, these species have been found in soil biological crusts on the technogenic substrates (Redkina et al. 2020). The likely explanation is that the accumulations of mucilaginous envelopes of cyanobacteria create a favorable water regime for these species. 


\begin{tabular}{|c|c|c|c|c|c|c|}
\hline Distance from KAS, $\mathrm{km}$ & 0.5 & 2 & 5 & 10 & 20 & 50 \\
\hline \multicolumn{7}{|c|}{ Phylum Chlorophyta, Class Chlorophyceae } \\
\hline Borodinellopsis oleifera K.Schwarz & & & + & & & \\
\hline Bracteacoccus minor (Schmidle ex Chodat) Petrová & + & + & + & + & & + \\
\hline Chlamydocapsa lobata Broady & & & + & & + & + \\
\hline Chlamydomonas sp. & & & + & + & + & + \\
\hline Chlorococcum infusionum (Schrank) Meneghini & & & & & + & \\
\hline Chloromonas reticulata (Goroschankin) Gobi & + & + & & + & + & \\
\hline $\begin{array}{l}\text { Coelastrella terrestris (Reisigl) Hegewald \& } \\
\text { N.Hanagata }\end{array}$ & & & + & & + & + \\
\hline Coenochloris sp. & + & & + & + & & + \\
\hline Dictyochloris fragrans Vischer & & & & + & & \\
\hline Dictyococcus varians Gerneck & + & + & & + & + & \\
\hline Ettlia minuta (G.Arce \& Bold) J.Komárek & & + & & & & \\
\hline Halochlorella rubescens P.J.L.Dangeard & & & + & + & + & + \\
\hline Monoraphidium terrestre (Bristol) Krienitz \& Klein & & + & + & + & + & + \\
\hline $\begin{array}{l}\text { Neocystis brevis (W.Vischer) I.Kostikov \& } \\
\text { L.Hoffmann }\end{array}$ & + & + & + & & + & + \\
\hline Pleurastrum terricola (Bristol) D.M. John & + & + & + & + & + & + \\
\hline $\begin{array}{l}\text { Radiosphaera negevensis Ocampo-Paus \& } \\
\text { Friedmann }\end{array}$ & + & + & + & + & + & + \\
\hline $\begin{array}{l}\text { Sporotetras polydermatica (Kützing) I.Kostikov, } \\
\text { T.Darienko, A.Lukesová, \& L.Hoffmann }\end{array}$ & + & + & + & + & & \\
\hline Tetracystis sp. & & & + & + & & + \\
\hline Tetraspora gelatinosa (Vaucher) Desvaux & & & + & & & \\
\hline
\end{tabular}

\section{Class Trebouxiophyceae}

Chloroidium saccharophilum (W.Krüger) Darienko, Gustavs, Mudimu, Menendez, Schumann, Karsten,

Friedl \& Proschold

Chlorella viscosa Chodat

Dictyochloropsis splendida Geitler

Diplosphaera chodatii Bialosukniá

Elliptochloris bilobata Tschermak-Woess

Elliptochloris reniformis H.Ettl \& G.Gärtner

Elliptochloris subsphaerica (Reisigl) Ettl \& Gärtner

Keratococcus bicaudatus (A.Braun ex Rabenhorst)

J.B.Petersen

Myrmecia biatorellae J.B.Petersen

Myrmecia bisecta Reisigl

Parietochloris alveolaris (Bold) Shin Watanabe \&

G.L.Floyd in Deason, Silva, Watanabe \& Floyd

Pseudococcomyxa simplex (Mainx) Fott

Stichococcus bacillaris Nägeli

Stichococcus minutus Grintzesco \& Peterfi

Stichococcus mirabilis Lagerheim in Wittrock \&

Nordstedt

Trochisciopsis tetraspora Vinatzer

Watanabea reniformis N.Hanagata, I.Karube,

M.Chihara \& P.C.Silva 
Xylochloris cf. irregularis Neustupa, Eliás \& Skaloud

\section{Class Ulvophyceae}

Fottea stichococcoides Hindák

Interfilum massjukiae Mikhailyuk, Sluiman,

Massalski, Mudimu, Demchenko, Friedl \&

Kondratyuk

Interfilum terricola (J.B.Petersen) Mikhailyuk,

Sluiman, Massalski, Mudimu, Demchenko, Friedl \& $+\quad+\quad+\quad+\quad+\quad+$

Kondratyuk

Planophila bipyrenoidosa Reisigl

\section{Phylum Charophyta, Class Klebsormidiophyceae}

Klebsormidium dissectum (F.Gay) H.Ettl \& Gärtner $\quad+\quad+\quad+$

Klebsormidium flaccidum (Kützing) P.C.Silva,

K.R.Mattox \& W.H.Blackwell

Klebsormidium montanum (Hansgirg) Shin

Watanabe

Klebsormidium pseudostichococcus (Heering) H.Ettl

\& Gärtner

Klebsormidium subtile (Kützing) Mikhailyuk,

Glaser, Holzinger \& Karsten

\section{Class Conjugatophyceae}

Cylindrocystis brebissonii (Ralfs) De Bary

Phylum Ochrophyta, Class Xanthophyceae

Botrydiopsis eriensis J.W.Snow

Botrydiopsis arhiza Borzì

$+++$

Botrydiopsis constricta Broady

Characiopsis minuta (A.Braun) Borzì

Xanthonema exile (Klebs) P.C.Silva

\section{Class Eustigmatophyceae}

Pseudocharaciopsis ovalis (Chodat) D.J.Hibberd

Vischeria magna (J.B.Petersen) Kryvenda, Rybalka,

Wolf \& Friedl

\section{Class Bacillariophyceae}

Pinnularia borealis Ehrenberg

Pinnularia viridis (Nitzsch) Ehrenberg

\section{Phylum Cyanobacteria, Class Cyanophyceae}

Aphanocapsa muscicola (Meneghini) Wille

Leptolyngbya $\mathrm{sp}$.

Microcoleus sp.

Microcoleus vaginatus Gomont ex Gomont

Nostoc sp.

Phormidium sp.

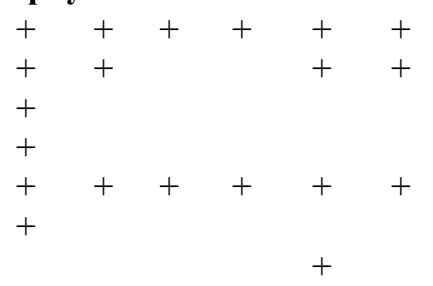

Stigonema sp.

Table 3. Species diversity of algae and cyanobacteria in the area of the Kandalaksha Aluminum Smelter. 
In earlier studies of the microbial component in the KAS zone, the absence of cyanobacteria was noted. Thus, it was concluded that photosynthetic prokaryotes are sensitive to both heavy metals and fluorine compounds (Evdokimova et al. 1997). However, our studies have shown that cyanobacteria in the maximum polluted zone are represented by six species. Their presence can be explained by several reasons. Firstly, cyanobacteria are tolerant to a variety of stress conditions due to the formation of mucilaginous envelopes, which constitute a physical barrier surrounding the cell (Kehr and Dittmann 2015). Secondly, it is known that some photosynthetic prokaryotes show passive permeation of both $\mathrm{HF}^{-}$ and $\mathrm{F}^{-}$across the cell membrane to reduce the toxic effects of fluorides (Nichol et al. 1987). In addition, cyanobacteria prefer a near-neutral $\mathrm{pH}$ level for their development (Shtina and Gollerbakh 1976) while at the closest distance from the pollution source, soil acidity decreases (Table 1). We suppose that the absence of cyanobacteria in previous studies is due to unsuccessful selection of the nutrient medium and in- sufficient cultivation duration.

No reliable correlation was found between the number of species in each plot and the fluorine content in the soil. However, as in the case of the number of viable cells, the species diversity in the area at a distance of $2 \mathrm{~km}$ from KAS is noticeably lower than in the zone of maximum contamination and in the less polluted soils.

Despite the high fluorine concentration $(>1000 \mathrm{mg} / \mathrm{kg}$ ), the number and diversity of microphotrophs in soils near KAS are relatively large. This may be due to a decrease in the toxicity of fluorine due to a decrease in its solubility in less acidic soils compared with the background region (Evdokimova et al. 2013). It is known that many algae and especially cyanobacteria prefer habitats with a $\mathrm{pH}$ close to neutral. The sparseness of the vegetation cover is also a favorable circumstance for the development of microphototrophs since it provides the sufficient illumination of the exposed areas and lack of competition between microphototrophs and higher plants for food sources.

\section{Conclusions}

31 species of soil fungi were isolated in the zone affected by the Kandalaksha Aluminum Smelter. The number, biomass, and diversity of soil fungi decreased as the results of the accumulation of a significant amount of fluorine in the soil near the smelter. The reduction of dark-colored fungi biomass in the fluorine contaminated soils was observed. The species $P$. trzebinskii and $P$. miczynskii dominated in the maximum polluted zone. P. glabrum, P. spinulosum, and Memnoniella echinata species prevailed in the zones with strong and moderately soil pollution. The share of opportunistic fungi increased in the contaminated soil. Rare or atypical species for zonal soils were isolated in polluted areas: Aspergillus niger var. niger, Paecilomyces

variotii, P. chermesinum, P. variabile, Pho ma medicaginis, Thielaviopsis basicola, Torula allii, Myxotrichum cancellatum, and Trichocladium asperum. Among these there are activators of opportunistic mycoses.

Altogether, 63 eukaryotic algae and cyanobacteria were identified in the soil samples within the pollution gradient from aerial technogenic emission of the KAS. Green algae dominated among the algal communities of investigated soils. The species diversity of cyanobacteria-algal cenoses in soils near KAS was higher than in the soils of unpolluted areas due to the presence of xanthophytes, a greater species diversity of filamentous algae from the genus Klebsormidium, as well as a larger number of cyanobacteria species. The dominance of 
filamentous forms in the cyanobacterial community, the abundance of coccoid green algae from the classes Chlorophyceae and Trebouxiophyceae, and the significant role of filamentous taxa (Klebsormidium, Xanthonema) are characteristic features of the Arctic biological soil crusts (Pushkareva et al. 2016). The number of algae and cyanobacteria in the litter varied from 100 thousand to 1.5 million cells per 1 gram of absolutely dry soil.

Strains of micromycetes, algae, and cy- anobacteria isolated from polluted soils in the studied zones are included into the Collection of the Laboratory of Terrestrial Ecosystems of the Institute of the Industrial Ecology Problems of the North (Apatity, Russia) which is registered in the international catalogue of world herbaria (INEP Herbarium of the Institute of the Industrial Ecology Problems of the North, Kola Science Center, Russian Academy of Sciences).

\section{References}

Andreeva, V. M. (1998): Soil and Aerophilic Green Algae. Moscow, Nauka, 351 p. (In Russian).

Armstrong, W. D., Singer, L. (1980): Fluoride: tissue distribution Intracellular fluoride concentration. Proceedings of the Society for Experimental Biology and Medicine, 164: 500506.

Arnesen, A. K. M., Krogstad, T. (1998): Sorption and desorption of fluoride in soil polluted from the aluminum smelter at Ardal in Western Norway. Water, Air, and Soil Pollution, 103(14): 357-373.

BARBer, M., TABereauX, A.T. (2014): The end of an era for Søderberg Technology in North and South America. In: J. Grandfield (ed.): Light Metals. Springer-Verlag, New York, pp. 809-814.

Berseneva, O. A, Salavarova, V. P, Pristavka, A.A. and Milentyev, V. A. (2010): Specific structure of soil mycocenoses in grey forest soils of the Pribaikalye subject to influence of emissions of Irkutsk aluminium plant. Vestnik Rossiiskogo Universiteta Druzhby Narodov. Seriya: Ekologiya I Bezopasnost' Zhiznedeyatel'nosti [RUDN Journal of Ecology and Life Safety], (1): 24-29. (In Russian).

BERSENEVA, O. A. (2015): Characteristic of the prokaryotic community isolated from gray forest soils located on the territories adjacent to the IrkAZ-RUSAL OJSC. Vestnik Mariiskogo Gosudarstvennogo Universiteta, Seriya Sel'skokhozyaistvennye nauki. Ekonomicheskie nauki [Bulletin of Mari State University. Chapter "Agriculture. Economics"],(4): 19-24. (In Russian).

Bhatnagar, M., Bhatnagar, A. (2000): Algal and cyanobacterial responses to fluoride. Fluoride, 33(2): 55-65.

CAmargo, J. A. (2003): Fluoride toxicity to aquatic organisms: A review. Chemosphere, 50: 251264.

CHASCHIN, V. (2007): The occurrence of fluorosis among pot room workers. Paper presented at the $3^{\text {rd }}$ International Conference on Environmental, Health and Safety Aspects Related to Production of Aluminum. Loen, Norway, $63 \mathrm{p}$.

Demidenko, G. A., ZhBankichov, D. O. (2014): The water-soluble fluorine influence on soil pollution in the zone of aluminum plant industrial emissions. Vestnik Krasnoiarskogo Gosudarstvennogo Agrarnogo Universiteta [Bulletin of KrasSAU], (5): 116-119. (In Russian).

Domracheva, L. I., Dabah, E. V., Kondakova, L. V. and Varaksina, A. I. (2006): Algomycological and phytotoxic complexes in chemical soil pollution. Paper presented at the XIII All-Russian School Ecology and Soils, Pushchino, Russia. pp. 88-99.

Domsch, K. H., GAMs, W. and ANDERSON. T. H. (2007): Compendium of Soil Fungi, $2^{\text {nd }}$ ed. IHWVerlag, Eching. 672 p.

Egorova, L. N. (1986): Soil Fungi of the Far East. Leningrad: Nauka. 192 p. (In Russian).

EtTl, H., GARTNER, G. (2014): Syllabus der Boden-, Luft- und Flechtenalgen. Berlin: SpringerVerlag. $773 \mathrm{p}$. 
Evdokimova, G. A., Korneikova, M. V. and Mozgova, N. P. (2013): Changes in the properties of soils and soil biota in the impact zone of the aerotechnogenic emissions from the Kandalaksha Aluminum Smelter. Eurasian Soil Science, 46(10): 1042-1048.

Evdokimova, G. A., Mozgova, N. P. (1996): Microflora of tundra soils in the Kola Peninsula. Eurasian Soil Science, 28(12): 188-203.

Evdokimova, G. A., Mozgova, N. P. and Shtina, E. A. (1997): Soil pollution by fluorine and evaluation of the soil microflora status in the area of influence of an aluminum plant. Eurasian Soil Science, 30(7): 796-803.

Evdokimova, G.A., Zenkova, I.V. and Mozgova, N. P. (2005): Soil and Soil Biota under Conditions of the Fluorine Contamination. Apatity: Kola Science Centre. 155 p. (In Russian).

Gaisina, L. A., FAZlutdinova, A. I. and Kabirov, R. R. (2008): Modern Methods of Isolation and Cultivation of Algae. Ufa: Bashkir State Pedagogical University. 152 p. (In Russian).

Garcia-Gil, J.C., Kobza, J., Soler-Rovira, P. and JavorekovÁ, S. (2013): Soil microbial and enzyme activities response to pollution near an aluminium smelter. Clean - Soil, Air, Water, 41(5): 485-492.

Ghosh, M., BANerJeE, P. S. and RAY, H. S. (2014): Environmental pollution due to gaseous emissions during non-ferrous extraction processes. Russian Journal of Non-Ferrous Metals, 55(3): 263-269.

GiBBS, G. W., LABRECHE, F. (2014): Cancer risks in aluminum reduction plant workers. Journal of Occupational and Environmental Medicine, 56: 40-59.

GUTKNECHT, J., WALTER, A. (1981): Hydrofluoric and nitric acid transport through lipid bilayer membranes. Biochimica et Biophysica Acta, 644: 153-156.

Kehr, J. C., Dittmann, E. (2015): Biosynthesis and function of extracellular glycans in cyanobacteria. Life, 5(1): 164-180.

Kirillova, N. N., Pomazkina, L. V. (2014): Influence of level of pollution by fluorides of aluminum production on degradation of gray forest soils of the Baikal region. Izvestiya Vuzov. Prikladnaya Khimiya i Biotekhnologiya [Proceedings of Universities. Applied Chemistry and Biotechnology], 5(10): 82-87.

KLICH, M. A. (2002): Identification of common Aspergillus species. CBS Fungal Biodiversity Centre, Utrecht, Netherlands, $116 \mathrm{p}$.

KomÁreK, J. (2013) Cyanoprokaryota: $3^{\text {rd }}$ Part: Heterocystous Genera. In: B. Büdel, G. Gärtner, L. Krienitz and M. Schagerl (Eds.): Süßwasserflora von Mitteleuropa, Bd. 19 (3), Springer Spektrum, Berlin, Heidelberg, 1-1130 p.

KomÁReK, J., ANAGNostidis, K. (2005): Cyanoprokaryota. 2. Teil: Oscillatoriales. In: B. Büdel, G. Gärtner, L. Krienitz and M. Schagerl (Eds.): Süßwasserflora von Mitteleuropa, Bd. 19 (2), Elsevier GmbH, München, 759 p.

KomÁReK, J., Anagnostidis, K. (1998): Cyanoprokaryota 1. Teil: Chroococcales. In: H. Ettl, G. Gärtner, H. Heynig, D. Mollenhauer (Eds): Süsswasserflora von Mitteleuropa 19/1, Gustav Fischer, Jena-Stuttgart-Lübeck-Ulm, 548 p.

Kondrat'eva, N. V., Kovalenko, O. V. (1975): Brief Guide for Identification of Toxic BlueGreen Algae. Kiev: Naukova Dumka [Scientific Thought Publishing House]. 64 p. (In Russian).

Kongerud, J. (2007): Hydrogen fluoride and health effects. Book of abstracts of the $3^{\text {rd }}$ international conference on environmental, health and safety aspects related to the production of aluminium. Loen, Norway, pp. 44-45.

KotAI, J. (1972): Instructions for the preparation of modified nutrient solution Z8 for algae. Norwegian Institute for Water Research, Blindern, Oslo:11/69. 5 p.

Kozlova, A. A., Lopatovskaya, O. G., Granina, N. I., Chipanina, E. V., Kuchmenko, E. V. and Bobrov, A. N. (2011): Fluoride contamination of gray forest soils from Irkutsk Aluminum Smelter (IrkAZ). Izvestiya Irkutskogo Gosudarstvennogo Universiteta, Seriya: Biologiya. Ecologiya, 4(1): 87-94 (In Russian).

KuRAKov, A. V. (2001): Manual for Isolation and Characterization of the Complexes of Micromycetes in Terrestrial Ecosystems. Moscow: MAKS Press. 92 p. (In Russian).

Larsen, S., Widdowson, A. (1971): Soil fluorine. Journal of Soil Science, 22: 210-221. 
Leslie, R., PARbery, D. G. (1972): Growth of Verticillium lecanii on medium containing sodium fluoride. Transactions of the British Mycological Society, 58(2): 351-352.

Lomovatskaya, L. A., Rykun, O. V., Simakova, A. A., Sokolova, M. G., Romanenko, A. S. and PomazkinA, L. V. (2014): Effect of high doses of fluoride in the soil on the activity of adenylyl cyclase signaling system of plants. Izvestiya Irkutskogo Gosudarstvennogo Universiteta, Seriya: Biologiya. Ecologiya. [The Bulletin of Irkutsk State University». Series «Biology. Ecology»], (7): 11-19 (In Russian).

MirchinK, T. G. (1988): Soil Mycology. Moscow, Moscow State University, 208 p. (In Russian).

Nichol, B. E., Budd, K., Palmer, G. R. and MacArthur, J. D. (1987): The mechanisms of fluoride toxicity and fluoride resistance in Synechococcusleopoliensis (Cyanophyceae). Journal of Phycology, 23(4): 535-541.

NikOnOV, V. V., Koptsik, G. N. (1999): Acid Rains and Forest Soils. Apatity: Kola Scientific Center, Russian Academy of Sciences, 320 p. (In Russian).

NovakovskiI, A. B. (2004): Possibilities and Principles of Use of GRAPHS Software Module. Syktyvkar: Komi Scientific Center, Ural Branch, Russian Academy of Sciences, 31 p. (In Russian).

Olsen, R.A., Hovland, J. (1985): Fungal Flora and Activity in Norway Spruce Needle Litter: Report. As: Agricultural University of Norway, $41 \mathrm{p}$.

Pomazkina, L. V., Kotova, L. G., Zorina, S. Yu., Rybakova, A. V. and Tikhonov, A. Yu. (2008): Carbon dioxide emission as affected by the properties of arable soils polluted with fluorides. Eurasian Soil Science, 41(2): 202-209.

PushikareVA, E., Johansen, J. R. and Elster, J. (2016): A review of the ecology, ecophysiology and biodiversity of microalgae in Arctic soil crusts. Polar Biology, 39(12): 2227-2240.

RAPER, B., THOM, C. (1968): A Manual of the Penicillia. London, Hafner, 875 p.

Redkina, V. V., Korneykova, M. V. and Shalygina, R. R. (2020): Microorganisms of the Technogenic Landscapes: The Case of Nepheline-Containing Sands, the Murmansk Region. Processes and Phenomena on the Boundary Between Biogenic and Abiogenic Nature. Springer, Cham, pp. 561-579.

Seifert, K., Morgan-Jones, G., Gams, W. and Kendrick, B. (2011): The Genera of Hyphomycetes, CBS Biodiversity Series No. 9. Utrecht, Netherlands: CBS-KNAW Fungal Biodiversity Centre, $997 \mathrm{p}$.

Shtina, E. A., GollerbaKh, M. M. (1976): Ecology of Soil Algae. Moscow: Nauka, 143 p. (In Russian).

SoKolova, L. G., Zorina, S. Yu. (2015): The study of field crops potential for phytoremediation of soils contaminated with fluorides of aluminum smelter. Izvestiya Vuzov. Prikladnaya Khimiya i Biotekhnologiya [Proceedings of Universities. Applied Chemistry and Biotechnology], 3(14): 61-68. (In Russian).

Sokolova, L. G., Zvyagintseva, E. N., Zorina, S. Yu., Kovaleva, N. N. and Pomazkina, L. V. (2011): Temporal Changes in the properties of fluoride polluted plowed gray forest soils and potentialities of their self-purification. Uspekhi Sovremennoi Biologii,131(6): 606-612. (In Russian).

Stevens, D. P., McLaughlin, M. J. and Alston, A. M. (1998): Phytotoxicity of hydrogen fluoride and fluoroborate and their uptake from solution culture by Lycopersicon esculentum and Avena sativa. Plant Soil, 200: 175-184.

Stevens, D. P., Mclaughlin, M. J., Randall, P. J. and Keerthisinghe, G. (2000): Effect of fluoride supply on fluoride concentrations in five pasture species: Levels required to reach phytotoxic or potentially zootoxic concentrations in plant tissue. Plant Soil, 227(1-2): 223-233.

Taiwo, B. (2007): The incidence of asthma among aluminum production workers. Paper presented at the 3rd International Conference on Environmental, Health and Safety Aspects Related to Production of Aluminum, 10-13 September, Loen, Norway. p. 41.

TANDelov, Yu. P. (2012): Fluoride in the Soil-Plant System. Krasnoyarsk: Russian Academy of Agricultural Sciences, 146 p. (In Russian).

Treshow, M. (1965): Response of some pathogenic fungi to sodium fluoride. Mycologia, 57(2): 216-221. 
V. V. REDKINA et al.

\section{Web sources / Other sources}

[1] List of aluminum smelters. Wikipedia.

https://en.wikipedia.org/w/index.php?title=List_of_aluminium_smelters\&oldid=859653159

[2] CABI databases (Species Fungorum database)

http://www.speciesfungorum.org

[3] AlgaeBase

http://www.algaebase.org 